\title{
KAJIAN KUAT TEKAN MORTAR PASIR SUNGAI BERLUMPUR DENGAN MENGGUNAKAN BAHAN TAMBAH DIFA SOIL STABILIZER
}

\author{
Agung Nusantoro ${ }^{1}$ dan Febby Surya Pambudi ${ }^{2}$
}

1Prodi Teknik Sipil, Universitas Muhammadiyah Purworejo, Jl. KHA Dahlan 3, Purworejo, 54111

Email korespondensi: agungnusantoro@umpwr.ac.id

2Prodi Teknik Sipil, Universitas Muhammadiyah Purworejo, Jl. KHA Dahlan 3, Purworejo, 54111

Email : suryanurkariim@gmail.com

\begin{abstract}
ABSTRAK
Pasir merupakan salah satu material bahan bangunan yang sering digunakan. Pasir mudah didapatkan di sungai, gunung, dan pantai yang terdapat kandungan lumpurnya. Sebagai syarat sebagai bahan konstruksi, salah satunya adalah bahwa kandungan lumpur dalam pasir tidak boleh melebihi 5\%. Kualitas pasir yang didapatkan di area penambangan juga dipengaruhi oleh cuaca, dimana pada saat musim penghujan kualitas pasir berbeda dengan pada saat musim kemarau. Tujuan penelitian ini adalah pasir yang mengandung lumpur lebih dari 5\% dapat digunakan sebagai bahan konstruksi dengan menambahkan soil stabilizer. Soil stabilizer merupakan bahan penstabil tanah yang akan digunakan sebagai bahan tambah dalam pembuatan mortar yang pasirnya mengandung lumpur lebih dari 5\%. Dalam penelitian ini menggunakan metode eksperimental dilaksanakan di laboratorium dengan menggunakan pendekatan lapangan. Dalam penelitian ini menggunakan pasir Sungai Bogowonto dan Sungai Gebang dari Purworejo yang tidak pernah digunakan sebagai bahan konstruksi dikarenakan kandungan lumpurnya diatas $5 \%$. Variasi bahan tambah soil stabilizer yang digunakan adalah $1 \%, 1.25 \%, 1.5 \%, 1.75 \%$, dan 2\% dari berat semen. Dari hasil penelitian diadapatkan berat jenis pasir gebang $2.63 \mathrm{~kg} / \mathrm{cm}^{3}$, dan sungai bogowonto $2.59 \mathrm{Kg} / \mathrm{cm}^{3}$, modulus halus butir sungai gebang 2.874, dan sungai bogowonto 2.85, kandungan lumpur sungai gebang 6.7\%, sungai bogowonto $14.87 \%$. Dalam pembuatan benda uji mortar dengan ukuran $5 \times 5 \times 5 \mathrm{~cm}$ dengan umur benda uji 7, 14, dan 28 hari. Hasil uji kuat tekan mortar tertinggi sungai gebang 23.63 MPa pada penambahan soil stabilizer $1.75 \%$ sedangkan sungai bogowonto $12.94 \mathrm{MPa}$ pada penambahan soil stabilizer 1.5\%. Dengan penambahan proporsi soil stabilizer yang tepat pada pasir berlumpur akan meningkatkan kuat tekan mortar.
\end{abstract}

Kata kunci: Pasir lumpur, Mortar, Soil Stabilizer

\begin{abstract}
Sand is a building material that is often used. Sand is easily found in rivers, mountains, and beaches where there is mud. As a condition as a construction material, one of which is that the silt content in the sand must not exceed 5\%. The quality of sand obtained in the mining area is also influenced by the weather, where during the rainy season the quality of sand is different from during the dry season. The purpose of this research is sand that contains more than 5\% mud can be used as a construction material by adding soil stabilizer. Soil stabilizer is a soil stabilizer that will be used as an additive in the manufacture of mortars whose sand contains more than 5\% mud. In this study using an experimental method carried out in the laboratory using a field approach. In this study using sand from the Bogowonto River and the Gebang River from Purworejo which have never been used as construction materials because the mud content is above 5\%. The variations of the added material used for soil stabilizer are 1\%, 1.25\%, 1.5\%, 1.75\%, and $2 \%$ by weight of cement. The results showed that the specific gravity of Gebang sand was $2.63 \mathrm{~kg} / \mathrm{cm} 3$, and the Bogowonto river was $2.59 \mathrm{~kg} / \mathrm{cm} 3$, the fine modulus of grain of the Gebang River was 2.874, and the Bogowonto River was 2.85, the mud content of the Gebang River was 6.7\%, the Bogowonto River was 14.87. \%. In the manufacture of mortar specimens with a size of $5 \times 5 \times 5 \mathrm{~cm}$ with ages of 7,14 , and 28 days of specimens. The results of the mortar compressive strength test, the highest mortar river $23.63 \mathrm{MPa}$ on the addition of soil stabilizer 1.75\% while the Bogowonto river $12.94 \mathrm{MPa}$ on
\end{abstract}


the addition of soil stabilizer 1.5\%. Adding the correct proportion of soil stabilizer to muddy sand will increase the compressive strength of the mortar.

Keywords: Mud, Mortar, Soil Stabilizer

\section{PENDAHULUAN}

Pasir sungai sudah tidak asing lagi bagi di dunia konstruksi, dimana pasir merupakan salah satu material untuk beton, spesi, plesteran. Menurut SNI 15-2049-2004 mortar merupakan suatu campuran yang terdiri dari semen, agregat halus dan air baik dalam keadaan dikeraskan ataupun tidak dikeraskan Kekuatan tekan mortar semen portland adalah gaya maksimum per satuan luas yang bekerja ada benda uji mortar semen portland berbentuk kubus dengan ukuran tertentu serta berumur tertentu.

Pasir sungai merupakan agregat halus yang berasal dari alam dan mempunyai butiran maksimum $4.76 \mathrm{~mm}$. Pasir sebagai agregat halus pembentuk mortar yang mana syaratsyarat sebagai agregat halus harus terpenuhi seperti yang disyaratkan pada SNI 03-6820-2002.

Semen Portland Pozzoland menurut SNI 150302-2004 adalah suatu semen hidrolis yang terdiri dari campuran yang homogen antara semen portland dengan pozolan halus, yang di produksi dengan menggiling klinker semen portland dan pozolan bersama-sama, atau mencampur secara merata bubuk semen portland dengan bubuk pozolan, atau gabungan antara menggiling dan mencampur, dimana kadar pozolan $6 \%$ sampai dengan $40 \%$ massa semen portland pozolan.

Menurut SNI 03-6820-2002 kandungan lumpur pada agregat halus yang digunakan tidak boleh melebihi 5\% [2]. Pasir yang diperoleh dari sungai mempunyai kandungan lumpur yang beragam, dan pasir sungai yang didapat pada musim penghujan dapat mempunyai kandungan lumpur lebih dari 5\%. Dengan kandungan lumpur lebih dari 5\% akan mempengaruhi kekuatan dari mortar tersebut. Dan untuk melakukan pencucian pasir agar kandungan lumpur dibawah 5\% akan menambah waktu dan biaya. Dengan menggunakan bahan tambah soil stabilizer diharapkan partikel lumpur didalam pasir akan terikat dan tidak mempengaruhi kekuatan mortar. Proporsi campuran mortar yang ditambah dengan soil stabilizer akan memudahkan penggunaan pasir yang berlumpur dapat digunakan sebagai bahan konstruksi. Penelitian ini bertujuan untuk mengetahui kuat tekan mortar dengan bahan tambah soil stabilizer.

Difa Soil Stabilizer merupakan salah satu bahan aditif yang dapat digunakan dalam proses stabilisasi tanah. Bahan ini bekerja bersama semen yang mengakibatkan semen mengikat kuat pada permukaan tanah, pencampuran Difa SS dengan semen membentuk kristal-kristal yang menempati rongga kosong [1].

Penelitian yang dilakukan oleh Mochammad Qomaruddin, Ariyanto1, Yayan Adi Saputro, Sudarno tentang Analisa Kuat Tekan Mortar Beton Fly Ash Dari Industri Pltu Tanjung Jati B Jepara Dengan Menggunakan Pasir Sungai Tempur Kabupaten Jepara. Dari hasil penelitian didapat kuat tekan mortar ratarata yang tertinggi pada campuran semen $80 \%$ dengan fly ash $20 \%$ sebesar $8,63 \mathrm{MPa}$ dan campuran semen $70 \%$ dengan fly ash $30 \%$ sebesar 8,57 MPa. Sedangkan yang memiliki kuat tekan terendah pada campuran semen $50 \%$ dengan fly ash $50 \%$ sebesar 5,05 $\mathrm{MPa}$. Persentasi fly ash $>30 \%$ berturut-turut menghasilkan kuat tekan lebih rendah[7].

Pipit Salmonda dalam penelitiannya Analisa Penggunaan Pasir Pantai Sebagai Pengganti Agregat Halus Terhadap Kuat Tekan Mortar, menunjukkan bahwa penggunaan pasir pantai sebagai alternatif bahan pengisi 
mortar dari hasil pengujian kubus menunjukkan kuat tekan rata-rata mortar dalam 14 hari sebesar $60,6 \mathrm{~kg} / \mathrm{cm} 2$ dalam penggunaan pasir pantai murni (tidak dicuci) dan $182,22 \mathrm{~kg} / \mathrm{cm} 2$ untuk nilai kuat rata-ratanya dalam 28 hari. Kemudian untuk nilai kuat tekan rata-rata penggunaan pasir pantai tidak murni (dicuci) sebesar 251,51 $\mathrm{kg} / \mathrm{cm} 2$ dalam 14 hari dan 336 [5].

Dalam penelitian yang dilakukan A. Nusantoro, N. Alami, dan N. Nurkholis dengan judul Analisis Kekuatan Cement Treated Base (CTB) Dengan Bahan Tambah Zat Aditif Menggunakan Variasi Kandungan Tanah menghasilkan CTB yang bercampur tanah dengan penambahan Difa Soil Stabilizer sebesar $5.3 \%$ mengalami kenaikan sebesar 33.162\% dan 73.902\%[2].

\section{METODOLOGI PENELITIAN}

Penelitian ini menggunakan metodologi eksperimental dengan pendekatan kondisi dilapangan yang dilakukan di laboratorium Universitas Muhammadiyah Purworejo. Tahapan penelitian yang akan menjadi dasar dalam pelaksanaan dalam penelitian ini adalah sebagai berikut:

1. Melakukan kajian literatur berupa buku, jurnal ilmiah, Prosiding, serta informasi yang terkait dengan penelitian.

2. Pengambilan bahan uji dari Sungai Bogowonto dan Sungai Gebang di Kabupaten Purworejo.

3. Pemeriksaan berat jenis pasir dari ke dua sungai tersebut.

4. Pemeriksaan modulus halus butir (MHB) pasir untuk mengetahui gradasi dari agregat halus.

5. Pemeriksaan kandungan lumpur dalam pasir.

6. Menentukan variasi komposisi soil stabilizer (Tabel 1).

7. Pembuatan benda uji dalam bentuk kubus ukuran $5 \times 5 \times 5 \mathrm{~cm}$

8. Perawatan benda uji dengan cara direndam.
9. Pengujian benda uji dan analisis

10. Pembahasan dan kesimpulan

Tabel 1. Perencanaan Campuran

\begin{tabular}{lll}
\hline Sample & $\begin{array}{l}\text { Soil Stabi- } \\
\text { lizer }\end{array}$ & Pasir:Semen:Air \\
\hline A & $0 \%$ & $1: 2,75: 0,482$ \\
\hline B & $1 \%$ & $1: 2,75: 0,482$ \\
\hline C & $1,25 \%$ & $1: 2,75: 0,482$ \\
\hline D & $1,5 \%$ & $1: 2,75: 0,482$ \\
\hline E & $1,75 \%$ & $1: 2,75: 0,482$ \\
\hline F & $2 \%$ & $1: 2,75: 0,482$ \\
\hline
\end{tabular}

\section{HASIL DAN PEMBAHASAN}

Hasil penelitian yang dilakukan di labortorium Fakultas Teknik, Universitas Muhammadiyah Purworejo adalah sebagai berikut :

\section{Berat jenis pasir}

Berat jenis pasir sungai gebang dan sungai bogowonto dapat dilihat pada tabel 2 .

Tabel 2. Berat Jenis Pasir

\begin{tabular}{llc}
\hline No & Sungai & Berat Jenis \\
\hline 1 & Gebang & 2.63 \\
\hline 2 & Bogowonto & 2.59 \\
\hline
\end{tabular}

Dari tabel 2 berat jenis sungai gebang lebih besar dari sungai bogowonto

\section{Modulus Halus Butir (MHB)}

Modulus halus butir (fitnes modulus) ialah suatu index yang dipakai untuk menjadi ukuran kehalusan atau kekasaran butirbutir agregat [6]. Makin besar nilai modulus halus menunjukkan bahwa semakin besar butir-butir agregatnya. Nilai MHB pada umumnya adalah antara $1.5-3.8$.

Uji MHB pasir Sungai Gebang dapat dilihat pada tabel 3 sebagai berikut: 
Tabel 3. Perhitungan MHB Pasir Sungai Gebang.

\begin{tabular}{llll}
\hline $\begin{array}{l}\text { Luban } \\
\text { Ayaka } \\
\boldsymbol{n}(\mathbf{m m})\end{array}$ & $\begin{array}{l}\text { Berat } \\
\text { Tertingga } \\
\boldsymbol{I} \text { (gram) }\end{array}$ & $\begin{array}{l}\text { Berat } \\
\text { Tertingga } \\
\text { I } \% \text { ) }\end{array}$ & $\begin{array}{l}\text { Berat } \\
\text { Tertingga } \\
\boldsymbol{I} \\
\text { Komulatif }\end{array}$ \\
\hline 4.8 & 1 & 0.2 & 0.2 \\
\hline 2.4 & 65 & 13 & 13.2 \\
\hline 1.2 & 103 & 20.6 & 33.8 \\
\hline 0.6 & 136 & 27.2 & 61 \\
\hline 0.3 & 106 & 21.2 & 82.2 \\
\hline 0.15 & 74 & 14.8 & 97 \\
\hline Sisa & 15 & 3 & --- \\
\hline Jumlah & 500 & 100 & 287.4 \\
\hline
\end{tabular}

$M H B=\frac{287.4}{100}=2.874$

Tabel 4. Perhitungan MHB Pasir Sungai Bogowonto.

\begin{tabular}{llll}
\hline $\begin{array}{l}\text { Luban } \\
\text { Ayaka } \\
\boldsymbol{n}(\mathbf{m m})\end{array}$ & $\begin{array}{l}\text { Berat } \\
\text { Tertingga } \\
\boldsymbol{I} \text { (gram) }\end{array}$ & $\begin{array}{l}\text { Berat } \\
\text { Tertingga } \\
\boldsymbol{I}(\%)\end{array}$ & $\begin{array}{l}\text { Berat } \\
\text { Tertingga } \\
\boldsymbol{I} \\
\text { Komulatif }\end{array}$ \\
\hline 4.8 & 1 & 0.4 & 0.4 \\
\hline 2.4 & 65 & 14.8 & 15.2 \\
\hline 1.2 & 103 & 15.8 & 31 \\
\hline 0.6 & 136 & 29 & 60 \\
\hline 0.3 & 106 & 21.2 & 81.2 \\
\hline 0.15 & 74 & 16 & 97.2 \\
\hline Sisa & 15 & 2.8 & --- \\
\hline Jumlah & 500 & 100 & 285.0 \\
\hline
\end{tabular}

$M H B=\frac{285.0}{100}=2.850$

Dari tabel 3 dan 4 disederhanakan menjadi tabel 5.
Tabel 5. MHB Pasir Sungai

\begin{tabular}{lll}
\hline No & Sungai & MHB \\
\hline 1 & Gebang & 2.874 \\
\hline 2 & Bogowonto & 2.850 \\
\hline
\end{tabular}

Untuk modulus halus butir dari kedua sungai hampir sama.

Pemeriksaan gradasi agregat halus (pasir) dibuat dalam sebuah grafik untuk mengetahui kategori pasir.

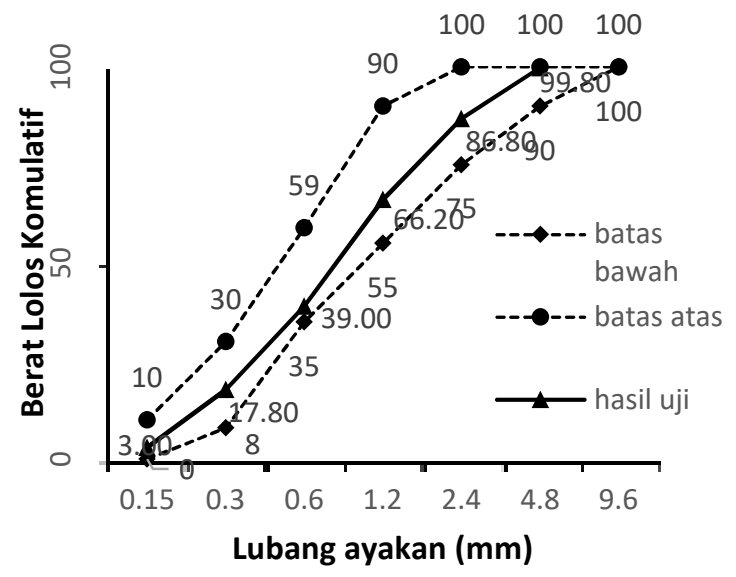

Gambar 1. Grafik Gradasi Agregat Halus Daerah II Pasir Sungai Gebang

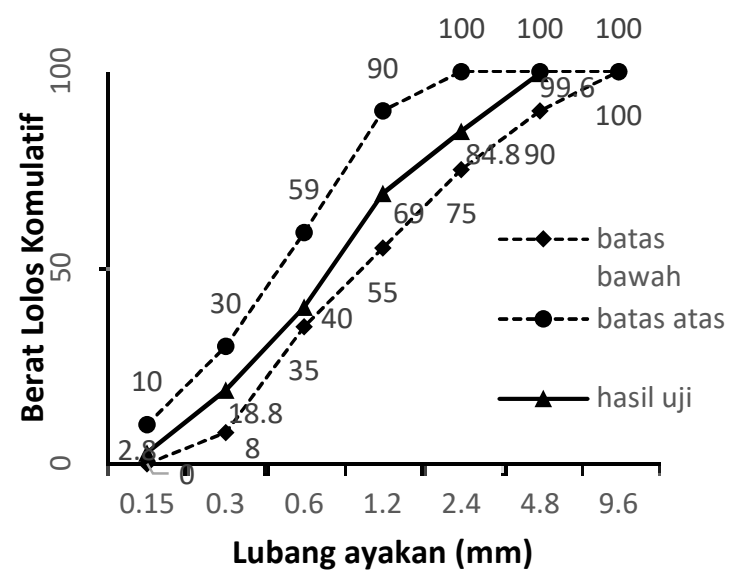

Gambar 2. Grafik Gradasi Agregat Halus Daerah II Pasir Sungai Bogowonto

Dari Gambar 1 dan 2 hasil pemeriksaan gradasi agregat halus masuk dalam daerah II yaitu termasuk pasir agak kasar. 


\section{Kandungan lumpur}

Kandungan lumpur sungai gebang dan sungai bogowonto dapat dilihat pada tabel 6.

Tabel 6. Kandungan Lumpur Pasir

\begin{tabular}{llc}
\hline No & Sungai & Kandungan Lumpur \\
\hline 1 & Gebang & $6.7 \%$ \\
\hline 2 & Bogowonto & $14.87 \%$ \\
\hline
\end{tabular}

Dari tabel 6 kandungan lumpur ke dua sungai diatas $5 \%$, tetapi pasir sungai bogowonto sangat tinggi dua kali lipat dari sungai gebang.

\section{Uji meja leleh}

Uji meja leleh ini dilakukan untuk menentukan kebutuhan air campuran, hasil dari uji meja leleh dapat dilihat pada tabel 7 dan 8 sebagi berikut :

Tabel 7. Uji Meja Leleh Pasir S. Gebang

\begin{tabular}{lllll}
\hline No & $\begin{array}{l}\text { Air/ } \\
\text { Spesime } \\
n\end{array}$ & $\begin{array}{l}\text { Diame } \\
\text { ter } \\
\text { Awal }\end{array}$ & $\begin{array}{l}\text { Diame } \\
\text { ter } \\
\text { Uji }\end{array}$ & Flow \\
\hline 1 & 0.6 & 10 & 14.58 & $46 \%$ \\
\hline 2 & 0.8 & 10 & 21.18 & $112 \%$ \\
\hline 3 & 1.0 & 10 & 23.98 & $140 \%$ \\
\hline
\end{tabular}

Tabel 8. Uji Meja Leleh Pasir S. Bogowonto

\begin{tabular}{lllll}
\hline No & $\begin{array}{l}\text { Air/ } \\
\text { Spesime } \\
\text { n }\end{array}$ & $\begin{array}{l}\text { Diame } \\
\text { ter } \\
\text { Awal }\end{array}$ & $\begin{array}{l}\text { Diame } \\
\text { ter } \\
\text { Uji }\end{array}$ & Flow \\
\hline 1 & 0.7 & 10 & 14.08 & $41 \%$ \\
\hline 2 & 0.9 & 10 & 21.05 & $111 \%$ \\
\hline 3 & 1.1 & 10 & 24.15 & $142 \%$ \\
\hline
\end{tabular}

Berdasarkan SNI 6882-2014 Mortar dengan sifat kelecakan yang baik memiliki derajat (flow) antara 105\% - 115\%, maka untuk campuran pasir sungai gebang menggunakan air/spesimen 0.8, sedangkan campuran pasir sungai bogowonto menggunakan 0.9 seperti pada tabel 9 .

Tabel 9. Nilai Air/Spesimen berdasarkan Flow

\begin{tabular}{lll}
\hline $\begin{array}{l}\text { Pasir } \\
\text { Sungai }\end{array}$ & $\begin{array}{l}\text { Air/ } \\
\text { Spesimen }\end{array}$ & Flow \\
\hline Gebang & 0.8 & $112 \%$ \\
\hline Bogowonto & 0.9 & $111 \%$ \\
\hline
\end{tabular}

\section{Kuat tekan mortar}

Kuat tekan suatu bahan adalah kemampuan bahan dalam menahan beban atau gaya yang dikenakan per satuan luas. Nilai kuat tekan mortar didapat dengan melakukan pengujian menggunakan mesin uji dengan cara memberikan beban bertingkat terhadap benda uji kubus sampai retak/hancur. Dalam SNI-03-6825-2002 kuat tekan mortar didapat:

$$
\text { Kuat Tekan }=\frac{P \text { maks }}{A}
$$

Uji kuat tekan mortar dilaksanakan pada umur 7, 14, dan 28 hari. Hasil dari uji kuat tekan dapat dilihat pada tabel 10 dan 11 .

Tabel 10. Kuat Tekan Mortar Pasir Sungai Gebang.

\begin{tabular}{lllll}
\hline \multirow{2}{*}{ No } & $\begin{array}{l}\text { Soil } \\
\text { Stabi- } \\
\end{array}$ & \multicolumn{3}{c}{$\begin{array}{l}\text { Kuat Tekan Rata-rata } \\
\text { (MPa) }\end{array}$} \\
\cline { 3 - 5 } & & $\mathbf{7 ~ H a r i}$ & $\begin{array}{l}\mathbf{1 4} \\
\text { Hari }\end{array}$ & $\begin{array}{l}\mathbf{2 8} \\
\text { Hari }\end{array}$ \\
\hline 1 & $0 \%$ & 14.79 & 18.38 & 22.46 \\
\hline 2 & $1 \%$ & 14.93 & 19.00 & 23.08 \\
\hline 3 & $1.25 \%$ & 15.05 & 19.06 & 23.13 \\
\hline 4 & $1.5 \%$ & 15.28 & 19.45 & 23.39 \\
\hline 5 & $1.75 \%$ & 15.43 & 19.62 & 23.63 \\
\hline 6 & $2 \%$ & 15.35 & 19.54 & 23.32 \\
\hline
\end{tabular}

Kuat tekan mortar tertinggi pada pasir sungai gebang yaitu $23.63 \mathrm{MPa}$ pada penambahan soil stabilizer sebesar $1.75 \%$. 
Tabel 11. Kuat Tekan Mortar Pasir Sungai Bogowonto.

\begin{tabular}{lllll}
\hline \multirow{2}{*}{ No } & $\begin{array}{l}\text { Soil } \\
\text { Stabi- } \\
\end{array}$ & \multicolumn{3}{c}{$\begin{array}{c}\text { Kuat Tekan Rata-rata } \\
\text { (MPa) }\end{array}$} \\
\cline { 3 - 5 } & & $\mathbf{7}$ Hari & $\begin{array}{l}\mathbf{1 4} \\
\text { Hari }\end{array}$ & $\begin{array}{l}\mathbf{2 8} \\
\text { Hari }\end{array}$ \\
\hline 1 & $0 \%$ & 6.15 & 8.45 & 11.54 \\
\hline 2 & $1 \%$ & 6.31 & 9.03 & 11.92 \\
\hline 3 & $1.25 \%$ & 6.52 & 9.45 & 12.78 \\
\hline 4 & $1.5 \%$ & 6.65 & 9.66 & 12.94 \\
\hline 5 & $1.75 \%$ & 6.55 & 9.09 & 12.68 \\
\hline 6 & $2 \%$ & 6.47 & 8.76 & 12.13 \\
\hline
\end{tabular}

Kuat tekan mortar tertinggi pada pasir sungai bogowonto yaitu $12.94 \mathrm{MPa}$ pada penambahan soil stabilizer sebesar $1.5 \%$.

Data hasil uji kuat tekan mortar dibuat dalam grafik untuk memudahkan analisis dapat dilihat pada gambar 3 dan 4 .

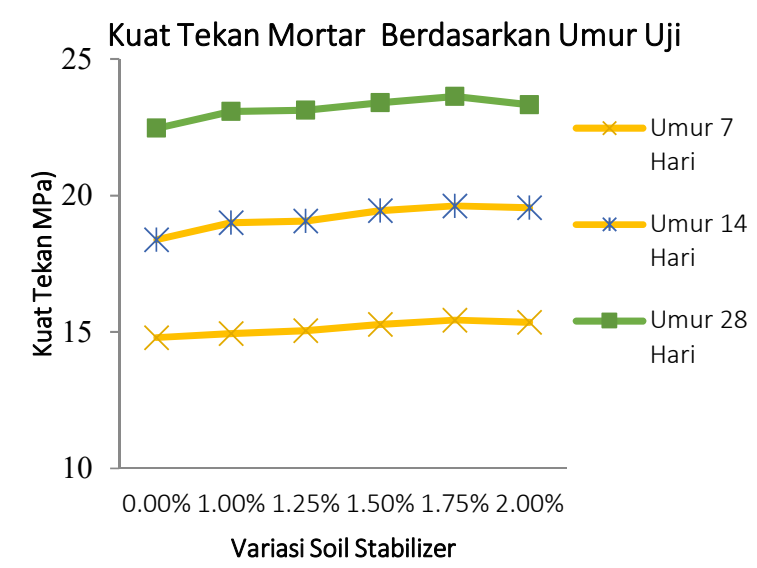

Gambar 3. Grafik Kuat Tekan Mortar Pasir Sungai Gebang umur 7, 14, dan 28 hari.

Dilihat tabel 10 dan gambar 3 pasir dari sungai gebang dengan hasil uji kuat tekan pada pasir tanpa penambahan soil stabilizer sebesar 22.46 dan kuat tekan tertinggi yaitu 23.63 MPa pada penambahan soil stabilizer 1.75\%. Ditinjau pada umur 28 hari ada kenaikan sebesar 1.17 MPa.

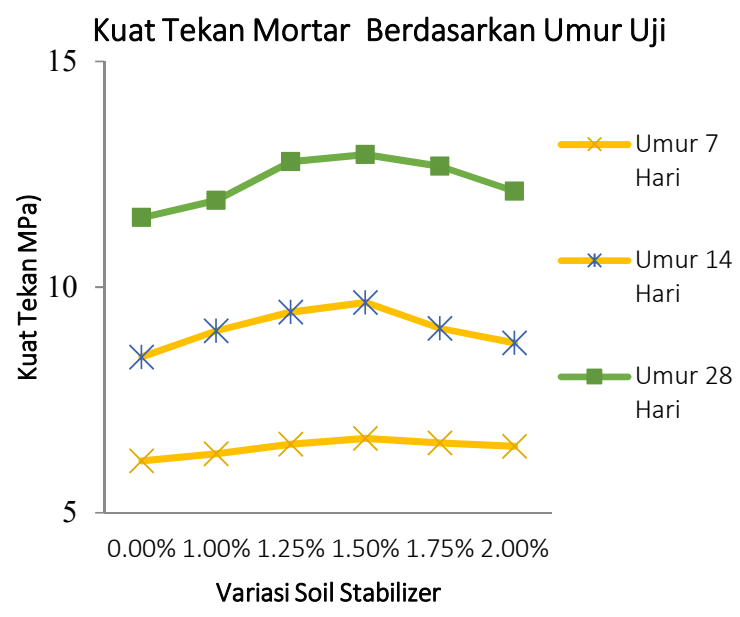

Gambar 4. Grafik Kuat Tekan Mortar Pasir Sungai Bogowonto umur 7, 14, dan 28 hari

Dilihat tabel 11 dan gambar 4 pasir dari sungai bogowonto dengan hasil uji kuat tekan pada pasir tanpa penambahan soil stabilizer sebesar 11.54 dan kuat tekan tertinggi yaitu 12.94 MPa pada penambahan soil stabilizer $1.5 \%$. Ditinjau pada umur 28 hari ada kenaikan sebesar 1.40 MPa. Untuk membandingkan hasil kuat tekan mortar dari pasir sungai gebang dan pasir sungai bogowonto dibuat dalam grafik pada gambar 5.

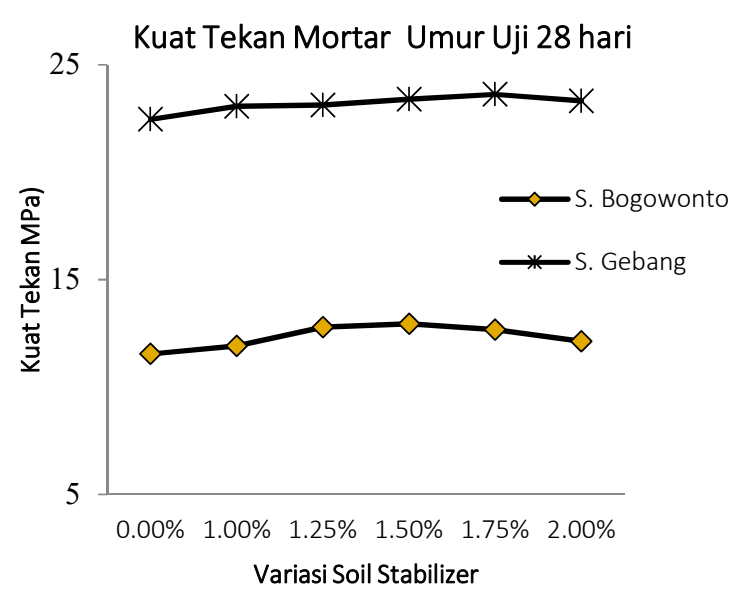

Gambar 5. Grafik Kuat Tekan Mortar Sungai Gebang dan Sungai Bogowonto Umur 28 Hari.

Dari gambar 5 menunjukkan kuat tekan mortar sungai gebang lebih tinggi 
dibandingkan dengan sungai bogowonto, dikarenakan kandungan lumpur tinggi dan berat jenis pasir dibawah pasir sungai gebang.

Dengan penambahan bahan Difa Soil Stabilizer kuat tekan mortar dengan menngunakan pasir sungai gebang dan pasir sungai bogowonto mengalami peningkatan dapat dilihat pada tabel 10 dan tabel 11 . Sehingga penambahan prosentase Difa Stabilizer pada campuran mortar yang menggunakan pasir sungai gebang dan sungai bogowonto sangat berpengaruh terhadap nilai kuat tekan mortarnya, dilihat baik dari data maupun grafik campuran mortar dengan penambahan Difa Soil Stabilizer menaikan nilai kuat tekan mortar tersebut.

Adapun selisih kenaikan kuat tekan mortar ditinjau dari campuran mortar tanpa penambahan Difa Soil Stabilizer dan umur mortar 7, 14, dan 28 hari dapat dilihat pada tabel 12, 13, dan 14 .

Tabel 12. Selisih Kuat Tekan Rata-rata Umur 7 Hari.

\begin{tabular}{lllll}
\hline \multirow{2}{*}{$\begin{array}{l}\text { Soil } \\
\text { Stabi- }\end{array}$} & \multicolumn{4}{c}{ Kuat Tekan Rata-rata (MPa) } \\
\cline { 2 - 5 } & $\begin{array}{l}\text { Sungai } \\
\text { Gebang }\end{array}$ & Selisih & $\begin{array}{l}\text { Sungai } \\
\text { Bowonto }\end{array}$ & Selisih \\
\hline $0 \%$ & 14.79 & 0.00 & 6.15 & 0.00 \\
\hline $1 \%$ & 14.93 & 0.14 & 6.31 & 0.16 \\
\hline $1.25 \%$ & 15.05 & 0.26 & 6.52 & 0.37 \\
\hline $1.5 \%$ & 15.28 & 0.49 & 6.65 & 0.50 \\
\hline $1.75 \%$ & 15.43 & 0.64 & 6.55 & 0.40 \\
\hline $2 \%$ & 15.35 & 0.56 & 6.47 & 0.32 \\
\hline
\end{tabular}

Kuat tekan mortar pada umur 7 hari (tabel 12) dengan penambahan Difa Soil Stabilizer mengalami kenaikan dan pada pasir sungai gebang mengalami penambahan kenaikan kuat tekan tertinggi sebesar 0.64 MPa pada penambahan Difa Soil Stabilizer sebesar $1.75 \%$, sedangkan pasir sungai bogowonto mengalami penambahan kenaikan kuat tekan tertinggi sebesar $0.5 \mathrm{MPa}$ pada penambahan Difa Soil Stabilizer sebesar $1.5 \%$.

Tabel 13. Selisih Kuat Tekan Rata-rata Umur 14 Hari.

\begin{tabular}{lllll}
\hline \multirow{2}{*}{$\begin{array}{l}\text { Soil } \\
\text { Stabi- } \\
\text { lizer }\end{array}$} & \multicolumn{4}{c}{ Kuat Tekan Rata-rata (MPa) } \\
\cline { 2 - 5 } & $\begin{array}{l}\text { Sungai } \\
\text { Gebang }\end{array}$ & Selisih & $\begin{array}{l}\text { Sungai } \\
\text { Bowonto }\end{array}$ & Selisih \\
\hline $0 \%$ & 18.38 & 0.00 & 8.45 & 0.00 \\
\hline $1 \%$ & 19.00 & 0.62 & 9.03 & 0.58 \\
\hline $1.25 \%$ & 19.06 & 0.68 & 9.45 & 1.00 \\
\hline $1.5 \%$ & 19.45 & 1.07 & 9.66 & 1.21 \\
\hline $1.75 \%$ & 19.62 & 1.24 & 9.09 & 0.64 \\
\hline $2 \%$ & 19.54 & 1.16 & 8.76 & 0.31 \\
\hline
\end{tabular}

Kuat tekan mortar pada umur 14 hari (tabel 13) dengan penambahan Difa Soil Stabilizer mengalami kenaikan dan pada pasir sungai gebang mengalami penambahan kenaikan kuat tekan tertinggi sebesar 1.24 MPa pada penambahan Difa Soil Stabilizer sebesar $1.75 \%$, sedangkan pasir sungai bogowonto mengalami penambahan kenaikan kuat tekan tertinggi sebesar $1.21 \mathrm{MPa}$ pada penambahan Difa Soil Stabilizer sebesar $1.5 \%$.

Tabel 14. Selisih Kuat Tekan Rata-rata Umur 28 Hari.

\begin{tabular}{lllll}
\hline \multirow{2}{*}{$\begin{array}{l}\text { Soil } \\
\text { Stabi- } \\
\text { lizer }\end{array}$} & \multicolumn{4}{c}{ Kuat Tekan Rata-rata (MPa) } \\
\cline { 2 - 5 } & $\begin{array}{l}\text { Sungai } \\
\text { Gebang }\end{array}$ & Selisih & $\begin{array}{l}\text { Sungai } \\
\text { Bowonto }\end{array}$ & Selisih \\
\hline $0 \%$ & 22.46 & 0.00 & 11.54 & 0.00 \\
\hline $1 \%$ & 23.08 & 0.62 & 11.92 & 0.38 \\
\hline $1.25 \%$ & 23.13 & 0.67 & 12.78 & 1.24 \\
\hline $1.5 \%$ & 23.39 & 0.93 & 12.94 & 1.40 \\
\hline $1.75 \%$ & 23.63 & 1.17 & 12.68 & 1.14 \\
\hline $2 \%$ & 23.32 & 0.86 & 12.13 & 0.59 \\
\hline
\end{tabular}

Kuat tekan mortar pada umur 28 hari (tabel 14) dengan penambahan Difa Soil Stabilizer 
mengalami kenaikan dan pada pasir sungai gebang mengalami penambahan kenaikan kuat tekan tertinggi sebesar $1.17 \mathrm{MPa}$ pada penambahan Difa Soil Stabilizer sebesar $1.75 \%$, sedangkan pasir sungai bogowonto mengalami penambahan kenaikan kuat tekan tertinggi sebesar $1.4 \mathrm{MPa}$ pada penambahan Difa Soil Stabilizer sebesar $1.5 \%$.

Tabel 15. Persentase Selisih Kuat Tekan Rata-rata Pasir Sungai Gebang

\begin{tabular}{llll}
\hline $\begin{array}{l}\text { Soil } \\
\text { Stabi- } \\
\text { lizer }\end{array}$ & \multicolumn{3}{c}{$\begin{array}{c}\text { Selisih Kuat Tekan Rata-rata } \\
\text { (\%) }\end{array}$} \\
\cline { 2 - 4 } & $\mathbf{7}$ Hari & $\mathbf{1 4 ~ H a r i}$ & $\mathbf{2 8 ~ H a r i}$ \\
\hline $0 \%$ & - & - & - \\
\hline $1 \%$ & 0.95 & 3.37 & 2.76 \\
\hline $1.25 \%$ & 1.76 & 3.70 & 2.98 \\
\hline $1.5 \%$ & 3.31 & 5.82 & 4.14 \\
\hline $1.75 \%$ & 4.33 & 6.75 & 5.21 \\
\hline $2 \%$ & 3.79 & 6.31 & 3.83 \\
\hline
\end{tabular}

Persentase selisih kuat tekan rata-rata pasir sungai gebang mengalami kenaikan penambahan kuat tekan yang tinggi pada umur 14 hari, dikarenakan pada umur 14 hari terjadi percepatan proses pengerasan mortar.

Tabel 16. Persentase Selisih Kuat Tekan Rata-rata Pasir Sungai Bogowonto

\begin{tabular}{llll}
\hline $\begin{array}{l}\text { Soil } \\
\text { Stabi- } \\
\text { lizer }\end{array}$ & \multicolumn{3}{c}{$\begin{array}{c}\text { Selisih Kuat Tekan Rata-rata } \\
(\%)\end{array}$} \\
\cline { 2 - 4 } & $\mathbf{7 ~ H a r i}$ & $\mathbf{1 4 ~ H a r i}$ & 28 Hari \\
\hline $0 \%$ & - & - & - \\
\hline $1 \%$ & 2.60 & 6.86 & 3.29 \\
\hline $1.25 \%$ & 6.02 & 11.83 & 10.74 \\
\hline $1.5 \%$ & 8.13 & 14.32 & 12.13 \\
\hline $1.75 \%$ & 6.50 & 7.57 & 9.88 \\
\hline $2 \%$ & 5.20 & 3.67 & 5.11 \\
\hline $2 \%$ & 3.79 & 6.31 & 3.83 \\
\hline
\end{tabular}

Sama dengan pasir sungai gebang persentase selisih kuat tekan rata-rata pasir sungai bogowonto mengalami kenaikan penambahan kuat tekan yang tinggi pada umur 14 hari, dikarenakan pada umur 14 hari terjadi percepatan proses kimiawi pengerasan mortar.

Dan apabila ditinjau pada umur 28 hari penambahan kuat tekan paling tinggi untuk pasir sungai gebang sebesar $5.21 \%$ dan pasir sungai bogowonto mengalami penambahan kuat tekan tertinggi sebesar 12.13\%. Dikarenakan kandungan lumpur pada pasir sungai bogowonto lebih tinggi dari pada pasir sungai gebang, maka kinerja Difa Soil Stabilizer dalam menstabilkan tanah lebih besar dari pada pasir sungai gebang.

\section{KESIMPULAN}

Berdasarkan hasil penelitian, analisis data, dan pembahasan yang dilakukan dihasilkan beberapa kesimpulan sebagai berikut :

1. Kuat tekan mortar maksimum pada umur 28 hari menggunakan pasir sungai gebang adalah $23.63 \mathrm{MPa}$ dan pada komposisi penambahan Difa Soil Stabilizer $1.75 \%$, sedangkan untuk pasir sungai bogowonto kuat tekan yang dihasilkan adalah $12.94 \mathrm{MPa}$ dan pada komposisi penambahan Difa Soil Stabilizer $1.5 \%$.

2. Pada umur 28 hari kenaikan kuat tekan pasir sungai gebang sebesar $1.17 \mathrm{MPa}$ atau ada kenaikan kuat tekan sebesar $5.21 \%$, sedangkan pasir sungai bogowonto mengalami kenaikan kuat tekan sebesar $1.4 \mathrm{MPa}$ atau mengalami kenaikan sebesar $12.13 \%$.

\section{DAFTAR PUSTAKA}

[1] Anonim. (2012). DIFA Soil Stabilizer. PT DIFA Mahakarya, Yogyakarta.

[2] Badan Standar Nasional. (2002). "SNI 03-6820-2002 Spesifikasi Agregat Halus Untuk Pekerjaan Adukan Dan Plesteran Dengan Bahan Dasar Semen". Jakarta. 
[3] Badan Standar Nasional. (2002). "SNI 03-6825-2002 Metode Pengujian Kekuatan Tekan Mortar Semen Portland Untuk Pekerjaan Sipil”. Jakarta.

[4] Nusantoro, A., Alami, N., Nurkholis, N. (2018)."Analisis Kekuatan Cement Treated Base (CTB) Dengan Bahan Tambah Zat Aditif Menggunakan Variasi Kandungan Tanah". URECOL, STIKES PKU Muhammadiyah Surakarta, 10 Februari 2018, 30-38

[5] Salmonda, Pipit. (2018). "Analisa Penggunaan Pasir Pantai Sebagai Pengganti agregat Halus Terhadap Kuat Tekan Mortar". Repository Medan Area University, Medan, 27-30.

[6] Tjokrodimulyo, K. (1992). Teknologi Beton. JTS-FT-UGM. Yogyakarta.

[7] Qomarudin, M., Ariyanto, Saputro Y.A., dan Sudarno (2018). "Analisa Kuat Tekan Mortar Beton Flay Ash Dari Industri PLTU Tanjung Jati B Jepara Dengan Menggunakan Pasir Sungai Tempur Kabupaten Jepara". Review In Civil Engineering, Vol. 2, 36-39. 
